\title{
Inside-Outside Circle Instructional Model For Multicultural Education
}

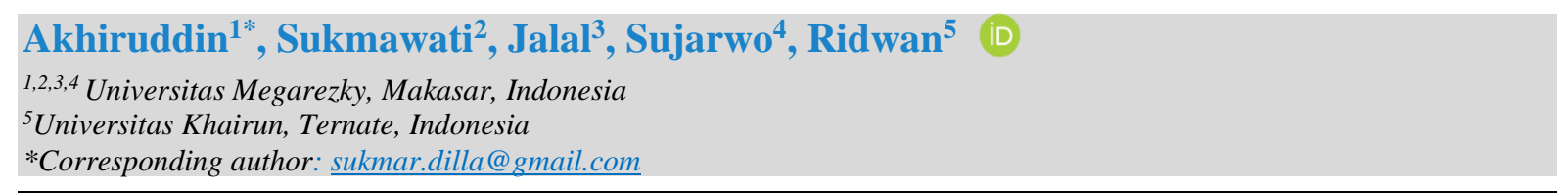

\begin{abstract}
Indonesia is one of the largest multicultural countries in the world. This reality can be seen through the diverse and extensive socio-cultural and geographical conditions. This study aims to investigate the implementation of the InsideOutside Circle (IOC) instructional model for the multicultural education. This research used qualitative and quantitative methods. Methods of data collection using observation, interviews and literature study. The results showed that multicultural education can be used as a strategic instrument to develop awareness of one's pride in one's ethnic group. Multicultural education is also very relevant to a pluralistic society such as Indonesia, which emphasizes an understanding of multiethnicity, multi-religion, and multiculturalism which requires a new construction of justice, equality and a democratic society. The application of integrative multicultural education can use a cooperative learning model, namely the InsideOutside Circle (IOC) linstructional model and the application of multicultural education in an integrated curriculum with other subjects such as in the Sociology Education program.
\end{abstract}

Keywords: Multicultural, Education, IOC

$\begin{array}{lll}\text { History: } & & \text { Publisher: Undiksha Press } \\ \text { Received } & \text { : March 19, 2021 } & \text { Licensed: This work is licensed under } \\ \text { Revised } & \text { : March 20, 2021 } & \text { a Creative Commons Attribution 3.0 License } \\ \text { Accepted } & \text { : June 20, 2021 } & \text { CC () () } \\ \text { Published } & \text { : July 25, } 2021 & \text { SA }\end{array}$

\section{INTRODUCTION}

Indonesia is one of the largest multicultural countries in the world (Perdana et al., 2019; Suradi, 2018). This reality can be seen through the diverse and extensive socio-cultural and geographical conditions (Perdana et al., 2019). Indonesia pluralism is shown by social differentiation in the form of ethnic, social, cultural, religious differences and so on (Afandi, 2018; Charles, 2017; Surahman, 2010). Multicultural education teaches mutual respect for differences, instils values of tolerance, mutual respect, maintains mutual understanding, openness in ethnic, racial, cultural and religious diversity (Amalia, 2017; Cahyono et al., 2017; Dey \& Bandyopadhyay, 2019; Lestariningsih \& Purnomo, 2018; Perdana et al., 2019; Wilson et al., 2017). It is an irrefutable fact that the Indonesian society and nation consists of various social, ethnic groups, cultures, religions, political aspirations and so on, so that "Indonesian society and nation can simply be called a" multicultural "society. On the other hand, this "multicultural" reality is faced with the urgent need to reconstruct the "Indonesian national culture" or "national culture" which can become an "integrating force" that can bind all of these ethnic, ethnic and cultural diversity (Arbabi et al., 2017; Bakri et al., 2020; Banks \& Banks, 2015; Hadirman \& Musafar, 2020; Hikam, 2015; Que, 2017; Sanaky, 2005; Sari, 2019; Szymanski et al., 2021; Ward et al., 2018; Wilson et al., 2017; Zhou \& Kwok, 2019).

Multicultural education is carried out based on the needs of students (society), in other words education from, by, and for the community which is organized with a responsibility that is centered on the integration and interconnection of interests between family, society and government (Amalia, 2017; Charles, 2017; Suradi, 2018). In understanding the multicultural insights of Sociology Education students, Faculty of Teacher Training and 
Education (FKIP) Megarezky University, a learning model is needed to discuss in the classroom, namely the implementation of the Inside-Outside Circle (IOC) learning model). It is a strategy that allows students to work cooperatively in sharing ideas, opinions, and information, and it can stimulate students' motivation and interaction in speaking activities (Tiwery, 2019). Inside Outside Circle Learning is a learning model developed by Spencer Kagan to provide opportunities for students to share information at the same time. Inside Outside Circle Learning develops an innovative and varied learning, (Akhiruddin \& Sujarwo, 2020; Haryanti, 2016). Inside Outside Circle learning steps are as follows: the lecturer explains the learning objectives; students are divided into several groups consisting of 4 people; each group gets the task of finding information based on the division of tasks from the lecturer (for example: story setting, story character, character, message, etc.); each selfstudy group, looking for information based on the assigned assignment; after completion, all students gather to mingle with each other (not based on groups); half the class then stands in a small circle and faces out; the other half of the class forms a circle outside the first circle, facing inward; two pairs of students from small and large circles share information. This information exchange can be done by all couples at the same time; then the students are in a small circle to stay in place, while the students who are in the big circle shift one or two steps clockwise; now it is the students' turn to be in the big circle for sharing information. And so on, until all students have finished sharing information (Dewi, 2017; Haryanti, 2016).

Several previous research results state that the strengthening of multiculturalism must continue to be strengthened through the education system in Islamic tertiary institutions. Multicultural-based Islamic education in Islamic tertiary institutions will strengthen the highest respect and appreciation for human dignity wherever it comes and whatever the culture. (Wakano \& Saidah, 2019). Then multicultural education in the curriculum is integrated with other subjects. The application of integrated multicultural education can use the cooperative learning model (IOC learning model). The basis for group formation in efficient cooperative learning by forming non-permanent groups by appointment of face-toface meetings or sessions. Habituation with the basis of the formation of varied groups in the cooperative learning model will develop the awareness that life now and in the future for students is no problem in adjustment. (Suparmi, 2013), Then it was strengthened by the results of the research that the students 'ability to understand mathematical concepts by applying the Inside Outside Circle learning model was better than the students' ability to understand mathematical concepts using conventional learning models. (Sri Yunita Ningsih, 2017). Based on the explanation above, this article would like to investigate the implementation of the Inside-Outside Circle (IOC) learning model for the multicultural education of Sociology Education students at Faculty of Teacher Training and Education (FKIP) Megarezky University.

\section{METHODS}

The research method is basically a scientific method used to obtain data for specific purposes and uses (Sugiyono, 2017). The methods used in this research were quantitative and qualitative. This method was carried out to obtain comprehensive data related to the problem being studied, namely examining the implementation of the Inside-Outside Circle (IOC) learning model for the multicultural education of Sociology Education students at Faculty of Teacher Training and Education (FKIP) Megarezky University. The subject of this research is students at Faculty of Teacher Training and Education (FKIP) Megarezky University. Data collection was carried out using three techniques, namely (1) observation, (2) in-depth interviews, and (3) literature study. The research instrument used is observation checklist, in- 
depth interview sheet, and literature study checklist. The collected data then analyzed using qualitative and quantitative approach.

\section{RESULTS AND DISCUSSION}

\section{Results}

After making observations or direct observations with students, lecturers who teach the Introduction to Education course and discussing, the researchers obtained some information, namely Sociology Education students, Faculty of Teacher Training and Education (FKIP) Megarezky University have so far disliked the fundamental of Education course because the learning model was less effective and creative along with the learning materials carried out by educators. This case occurred during the learning process there are no small groups or large groups in the class interaction process to construct students' thinking. This causes students to become passive in learning activities because they do not have the opportunity to develop thinking skills and find various alternatives to problem abuse and are very dependent on the lecturer.. Perspective of learning is not just looking at the situation, but here students learn, broaden their horizons, and become a new platform to prepare themselves in the future (Sujarwo et al., 2020).

Then an Inside Outside Circle learning model is applied, which is in the form of inner and outer circle groups that emphasize student activities to be active in sharing information with their themes and using time ranges every time a circle rotates. In addition, Inside Outside Circle-based learning is based on a constructivism approach which is based on the belief that students construct conceptual understandings by expanding or modifying existing knowledge. Inside Outside Circle also involves cooperative values and the active role of students in the learning process. Furthermore, the researchers conducted several interviews between students of Sociology Education students, Faculty of Teacher Training and Education (FKIP) Megarezky University and lecturers including:

Researcher : What do you think about the implementation of the IOC learning model in the fundamental of Education course with multicultural material in the Sociology Education study program, Megarezky University?

Riyanti : I think the implementation of the IOC Multicultural learning model is very suitable because multicultural education can be carried out through the formation and change of attitudes in students, for example by using indicators of social care, mutual respect, tolerance of followers of different religions, and so on.

Ovantius : Based on the results of our discussion in class that I really support the implementation of multicultural education in educational institutions, especially at Megarezky University.

Lecturer : The duty of a lecturer is not only required to master and be able to professionally teach the subjects being taught. It is an irrefutable fact that the Indonesian society and nation consists of various social, ethnic groups, cultures, religions, political aspirations and so on, so that "Indonesian society and nation can simply be called a" multicultural "society.

From the interview results above, it can be analyzed that understanding aspects of cultural, ethnic and other diversity is important in the midst of an increasingly global life. Students as people who are already in the process of education and have sufficient academic qualifications to be able to mingle with all the differences that exist as a necessity. It is not on the contrary to question the cultural existence of other people who are considered inferior (Maryono, 2019). In the era of globalization, every country is trying to produce effective 
education policies that can properly frame institutional support systems for the education of all children, including those from multicultural families (Lee et al., 2020). An individual who is born in the community does not build and create his own culture, but he is formed by the culture of his environment. The power that affects humans is not by the ability to create new thoughts, but is more influenced by the ability to adopt, transfer and carry out traditions (Sari, 2019). Furthermore, based on the observation of the implementation of the learning process through IOC instructional model in fundamental of education courses, it can be seen that the observer I assessment shows the mean score of 3.78 in good category, while the observer II score shows an overall average of 3, 94 in good category. This shows that the results of the classical observer's assessment of observer I and observer II are good category

\section{Discussion}

The results of the study state that firstly the interaction of lecturers and students of the Sociology Education study program against multicultural symbols results in a student's meaning of multiculturalism which is defined as mutual respect, respect, understanding and knowing the diversity of other people's cultures; The meaning of student multiculturalism is based on multiculturalism; second, the student multiculturalism perspective is formed by a multicultural environment and is inherited from the educational process carried out in the educational environment and family as well as idol figures and students who understand each other (Arbabi et al., 2017; Kadam et al., 2020). Whereas in the internal aspect, the student's multiculturalism perspective can also be formed through self-development with the addition of multiculturalism and thirdly, while the multiculturalism of students in their environment bases their social actions on traditional values, ethics and the values that are used as goals, then there was a positive relationship between an open attitude towards intercultural contact (Haenni Hoti et al., 2017).

Multiculturalism includes an understanding, appreciation as well as an assessment of one's culture, as well as a respect and curiosity about the ethnic culture of others (Lee et al., 2020; Szymanski et al., 2021). The continuity and development of local culture needs to be maintained and kept away from obstacles. The elements of local culture that are beneficial to oneself need to be further developed so that they can become part of the national culture, enrich the elements of national culture. However, as Indonesian professionals, our main mission is to transform multicultural reality as an asset and a source of national strength, making it a national synergy, strengthening convergence, diversity (Li, 2020). From the opinion of these experts, we can conclude that Multiculturalism is an idea, an idea, a world view where multi in the sense of many and culturalism is a culture so that multiculturalism is an idea that expresses the cultural diversity of a nation, a group of people where diversity becomes one pride and must be preserved by still adhering to the principle of diversity is togetherness. Teacher multiculturalism behavior in the realm of learning, manifested in the form of action that respects the cultural diversity of students and makes multiculturalism an implementation of the IOC learning model that is integrated into the objectives, methods, materials (Dewi, 2017; Haryanti, 2016).

The basis for efficient group formation is the formation of non-permanent groups with a session agreement or face-to-face meeting agreement, which allows students to take turns interacting with classmates. Habituation with the basis of the formation of varied groups in the cooperative learning model will develop the awareness that the present and future life for students is not a problem in adjustment. The meaning of the basic formation of this group in addition to Multicultural Education, which is to show that humans in life / working outside their families are not always what we want. For this we need to adjust to anyone, anywhere and can work with anyone with a different background so that implementation The InsideOutside Circle (IOC) learning model for the multicultural education of Faculty of Teacher 
Training and Education (FKIP) Megarezky University is carried out well and harmoniously in the classroom.

\section{CONCLUSION}

The implementation of multiculturalism towards IOC instructional model must be strengthened through the education system in higher education. Multicultural education is a form of awareness about cultural diversity. Multicultural education can be used as a strategic instrument to develop awareness of one's pride in one's ethnic of group. Multicultural education is also very relevant to a pluralistic society such as Indonesia, which emphasizes an understanding of multi-ethnicity, multi-religion, and multiculturalism which requires a new construction of justice, equality and a democratic society. The application of integrative multicultural education can use a cooperative learning model, namely the Inside-Outside Circle (IOC) instructional model and the application of multicultural education in an integrated curriculum with other subjects.

\section{REFERENCES}

Afandi, M. (2018). Potret Masyarakat Multikultural di Indonesia. Journal Multicultural of Islamic Education, 2(1), 1-10. https://jurnal.yudharta.ac.id/v2/index.php/ims/article/view/1219.

Akhiruddin; Sujarwo. (2020). The Implementation Of Instructional Materials Development Based On Inside Outside Circle ( IOC ) For Students' Sociology Education Of Megarezky University. JED (Journal of Etika Demokrasi), 5(1), 86-94. https://doi.org/10.26618/jed.v5i1.3041.

Amalia. (2017). Strategi Menanamkan Pendidikan Multikultural pada Siswa SMA Negeri 1 Sekincau Lampung Barat. UIN Raden Intan Lampung. http://repository.radenintan.ac.id/5839/1/TESIS\%20APRI.pdf.

Arbabi, K., Yeh, C. J., Mahmud, Z., \& Salleh, A. (2017). From Monocultural to Multicultural: Adaptation of Iranian Immigrant Adolescents in Malaysia. Journal of Adolescent Research, 32(3), 371-402. https://doi.org/10.1177/0743558416630811.

Bakri, M., Mistar, D., Ghony, M. D., \& Indah, N. (2020). Pesantren dan Multikulturalisme di Madura: Adaptasi Nilai Multikultural dalam Menciptakan Kerukunan Masyarakat Multi Etnis dan Agama. Jurnal Pendidikan Agama Islam (Journal of Islamic Education Studies), 8(2), 173-194. https://doi.org/10.15642/jpai.2020.8.2.173-194.

Banks, J. A., \& Banks, C. M. A. (2015). Multicultural Education: Issues and Perspectives. Wiley/Jossey-Bass Education.

Cahyono, H., Januar, A., \& Dan, M. (2017). Harmoni Masyarakat Tradisi Dalam Kerangka Multikuluralisme. Asketik, 1(1), 27-34. https://doi.org/10.30762/ask.v1i1.408.

Charles, C. (2017). Pendidikan Multikultural Untuk Memperkuat Kohesifitas Persatuan dan Kesatuan Bangsa. Jurnal Educative: Journal of Educational Studies, 2(1), 29-46. http://dx.doi.org/10.30983/educative.v2i1.319.

Dewi, C. (2017). Peningkatan Keterampilan Berbicara Dalam Bermain Drama Melalui Model Pembelajaran Kooperatif Tipe Inside-Outside Circle. JINoP (Jurnal Inovasi Pembelajaran), 3(2), 567-575. https://doi.org/10.22219/jinop.v3i2.4575.

Dey, P., \& Bandyopadhyay, S. (2019). Blended learning to improve quality of primary education among underprivileged school children in India. Education and Information Technologies, 24(3). https://doi.org/10.1007/s10639-018-9832-1.

Hadirman, \& Musafar. (2020). Fungsi Adaptasi Sosio-Kultural Komunitas Muna Perantauan dalam Masyarakat Multikultural di Kota Bitung Provinsi Sulawesi Utara. Jurnal 
Sosiologi Agama Indonesia (JSAI), $\quad$ I(2), 148-160. https://doi.org/10.22373/jsai.v1i2.559.

Haenni Hoti, A., Heinzmann, S., Müller, M., \& Buholzer, A. (2017). Psychosocial Adaptation and School Success of Italian, Portuguese and Albanian Students in Switzerland: Disentangling Migration Background, Acculturation and the School Context. Journal of International Migration and Integration, 18(1), 85-106. https://doi.org/10.1007/s12134-015-0461-X.

Haryanti, Y. D. (2016). Peningkatan Hasil Belajar Dengan Menggunakan Model Cooperative Learning Type Inside-Outside Circle. Jurnal Cakrawala Pendas, 2(2). https://doi.org/10.31949/jcp.v2i2.337.

Hikam, M. A. (2018). Pendidikan Multikultural dalam Rangka Memperkuat Kewaspadaan Nasional Menghadapi Ancaman Radikalisme di Indonesia. Global: Jurnal Politik Internasional, 17(1), 1-17. https://doi.org/10.7454/global.v17i1.26.

Kadam, R., Rao, S. A., Kareem Abdul, W., \& Jabeen, S. S. (2020). Diversity climate perceptions and its impact on multicultural team innovation and performance. Measuring Business Excellence, 24(3), 301-318. https://doi.org/10.1108/MBE-042019-0037.

Lee, S. J., Jahng, K. E., \& Kim, K. (2020). Light and shade of multicultural education in South Korea: Analysis through Bourdieu's concept of capital. Journal for Multicultural Education, 14(2), 149-161. https://doi.org/10.1108/JME-11-2019-0081.

Lestariningsih, W. A., \& Purnomo, A. (2018). Penanaman Nilai-Nilai Multikultural dalam Pembelajaran Sejarah di SMA Negeri 1 Rembang Tahun Pelajaran 2017/2018. Indonesian Journal of History Education, 6(2), 123-131. https://journal.unnes.ac.id/sju/index.php/ijhe/article/view/27636.

Li, C. (2020). A Positive Psychology perspective on Chinese EFL students' trait emotional intelligence, foreign language enjoyment and EFL learning achievement. Journal of Multilingual and Multicultural Development, 41(3), 246-263. https://doi.org/10.1080/01434632.2019.1614187.

Maryono. (2019). Pola Pengembangan Wawasan Multikultural di Ma'had Darul Arqam Muhammadiyah Kab. Garut Staf Pengajar FITK UNSIQ Wonosobo. Manarul Qur'an: Jurnal Ilmiah Studi Islam, 19(2), 94-114. https://doi.org/10.32699/mq.v19i2.1606.

Ningsih, S. Y., \& Andriani, S. (2017). Penerapan Model Pembelajaran Inside Outside Circle Terhadap Kemampuan Pemahaman Konsep Siswa. MES: Journal of Mathematics Education and Science, 2(2). https://doi.org/10.30743/mes.v2i2.136.

Perdana, Y., Sumargono, S., \& Rachmedita, V. (2019). Integrasi Sosiokultural Siswa Dalam Pendidikan Multikultural Melalui Pembelajaran Sejarah. Jurnal Pendidikan Sejarah, 8(2), 79-98. https://doi.org/10.21009/jps.082.01.

Que, S. R. (2017). Masyarakat Multikultural Dalam Cerminan Budaya Populer Amerika dan Indonesia. Jurnal Tahuri: Jurnal Ilmiah Pendidikan Bahasa, 14(10), 14-18. https://ojs3.unpatti.ac.id/index.php/tahuri/article/view/1375.

Sari, I. (2019). Strategi Kebudayaan Pembangunan Keberagamaan di Indonesia: Mempertegas Kontribusi Kearifan Budaya Lokal Dalam Masyarakat Berbhinneka. Studia Sosia Religia, 2, 63-77. http://dx.doi.org/10.51900/ssr.v2i2.6487.

Sugiyono. (2017). Pengertian Objek Penelitian. PT Remaja Rosdakarya

Sujarwo, S., Sukmawati, S., Akhiruddin, A., Ridwan, R., \& Suharti Siradjuddin, S. S. (2020). An Analysis of University Students' Perspective On Online Learning in The Midst of Covid-19 Pandemic. Jurnal Pendidikan Dan Pengajaran, 53(2), 125. https://doi.org/10.23887/jpp.v53i2.24964.

Suparmi, S. (2013). Pembelajaran Kooperatif dalam Pendidikan Multikultural. Jurnal Pembangunan Pendidikan: Fondasi Dan Aplikasi, 1(1), 108-118. 
https://doi.org/10.21831/jppfa.v1i1.1055.

Suradi, A. (2018). Pendidikan Berbasis Multikultural dalam Pelestarian Kebudayaan Lokal Nusantara di Era Globalisasi. Wahana Akademika: Jurnal Studi Islam Dan Sosial, $5(1)$, 111-130. https://www.journal.walisongo.ac.id/index.php/wahana/article/view/2566.

Surahman, S. (2010). Pendidikan Multikultural dalam Kehidupan Mahasiswa Madura di Yogyakarta. SOSIO-RELIGIA, 9(Khusus), 1-10. https://www.aifisdigilib.com/uploads/1/3/4/6/13465004/63_susilo_surahman-pendidikan.pdf.

Szymanski, M., Alon, I., \& Kalra, K. (2021). Multilingual and multicultural managers' effects on team performance: insights from professional football teams. Multinational Business Review, ahead-of-print(ahead-of-print). https://doi.org/10.1108/MBR-032020-0054.

Tiwery, S. D. (2019). Inside-Outside Circle As the Way in Building Students' Motivation and Interaction in Speaking Classroom Activities. International Journal of Language Education, 1(1), 33. https://doi.org/10.26858/ijole.v1i1.6703.

Wakano, A., \& Saidah, U. (2019). Reproduksi Gagasan Multikulturalisme di Perguruan Tinggi Islam di Indonesia. In LP2M IAIAN AMBON (Vol. 1, Issue 1). http://repository.iainambon.ac.id/3/1/Reproduksi\%20gagasan\%20multikulturalisme\% 20di\%20perguruan\%20tinggi\%20Islam\%20di\%20Indonesia.pdf.

Ward, C., Ng Tseung-Wong, C., Szabo, A., Qumseya, T., \& Bhowon, U. (2018). Hybrid and Alternating Identity Styles as Strategies for Managing Multicultural Identities. Journal of Cross-Cultural Psychology, 49(9), 1402-1439. https://doi.org/10.1177/0022022118782641.

Wilson, J., Ward, C., Fetvadjiev, V. H., \& Bethel, A. (2017). Measuring Cultural Competencies: The Development and Validation of a Revised Measure of Sociocultural Adaptation. Journal of Cross-Cultural Psychology, 48(10), 1475-1506. https://doi.org/10.1177/0022022117732721.

Zhou, D.-H. R., \& Kwok, H. L. (2019). Multicultural perspectives of help-seeking, stress coping and assessment adaptation. Asia Pacific Journal of Counselling and Psychotherapy, 10(2), 93-94. https://doi.org/10.1080/21507686.2019.1640970. 